\title{
Neospora caninum as causative agent of bovine encephalitis in Brazil
}

\author{
Neospora caninum como agente causal de encefalite bovina no Brasil \\ Jane Mary Albinati Malaguti ${ }^{1}$; Aline Diniz Cabral'²; Raisa Pereira Abdalla ${ }^{1}$; \\ Yolanda Oliveira Salgueiro ${ }^{1}$; Nara Thiers Cacciatori Galleti ${ }^{1}$; Liria Hiromi Okuda ${ }^{1}$; \\ Elenice Maria Sequetin Cunha ${ }^{1}$; Edviges Maristela Pituco ${ }^{1}$; Claudia Del Fava ${ }^{1 *}$
}

${ }^{1}$ Centro de Pesquisa e Desenvolvimento de Sanidade Animal - CPDSA, Instituto Biológico - IB

${ }^{2}$ Departamento de Medicina Veterinária Preventiva e Saúde Animal, Faculdade de Medicina Veterinária e Zootecnia - FMVZ, Universidade de São Paulo - USP

Received June 27, 2011

Aceepted 6 December, 2011

\begin{abstract}
For supporting the Brazilian bovine encephalitis surveillance program this study examined the differential diagnosis of Neospora caninum in central nervous system (CNS) by histological analysis (HE staining), immunohistochemistry (IHC), and nested-PCR using a set of primers from the Nc5 region of the genomic DNA and ITS1 region of the ribosomal DNA. A sample of 302 cattle presenting neurological syndrome and negative for rabies, aged 0 to 18 years, from herds in 10 Brazilian states was evaluated for $N$. caninum from January 2007 to April 2010. All specimens tested negative with IHC and nested-PCR using primers from the ITS1 region of ribosomal DNA, while two positive cases $(0.66 \%)$ were found using primers from the Nc5 region of genomic DNA: a 20 month-old male and a 72 month-old female, both from São Paulo State. Only the male presented severe multifocal necrotizing encephalitis associated with mononuclear cell infiltration, a pathognomonic lesion caused by parasites of the family Sarcocystidae, and only this case was associated with $N$. caninum thus representing $0.33 \%$ positivity. Future studies should explore the association of IHC and nested-PCR with real-time PCR, a quantitative method that could be standardized for improving the detection of N. caninum in bovine CNS specimens.
\end{abstract}

Keywords: Histopathology, immunohistochemistry, nested-PCR, Nc5, ITS1.

\section{Resumo}

Este estudo contribuiu para o programa de vigilância epidemiológica de encefalite bovina no Brasil realizando o diagnóstico diferencial de Neospora caninum no sistema nervoso central (SNC) por análise histológica (coloração HE), imunohistoquímica (IHC) e nested-PCR utilizando-se primers da região Nc5 do DNA genômico e da região ITS1 do DNA ribossomal. Um total de 302 amostras de bovinos com síndrome neurológica, negativos para raiva, na faixa etária de zero a 18 anos, provenientes de rebanhos de 10 estados brasileiros foi avaliada para $N$. caninum no período de janeiro/2007 a abril/2010. Todas as amostras foram negativas na IHC e na nested-PCR usando-se primers da região ITS1 do DNA ribossomal, enquanto dois casos $(0,66 \%)$ foram positivos à nested $\mathrm{PCR}$, usando-se primers da região Nc5 do DNA genômico: um macho de 20 meses de idade e uma fêmea de 72 meses de idade, ambos do Estado de Sáo Paulo. Apenas o macho apresentou severa encefalite multifocal necrotizante associada com infiltrado inflamatório mononuclear, lesão patognomônica causada por parasitas da família Sarcocystidae, mostrando que apenas este caso de encefalite foi associado à infecção por $N$. caninum, representando $0,33 \%$ de positividade. Sugere-se em estudos futuros utilizar também a PCR em tempo real para detecção do parasito.

Palavras-chave: Histopatologia, imunohistoquímica, nested-PCR, Nc5, ITS1.

\footnotetext{
*Corresponding author: Claudia Del Fava

Laboratório de Anatomia Patológica, Centro de Pesquisa e Desenvolvimento de Sanidade Animal - CPDSA, Instituto Biológico, Av. Conselheiro Rodrigues Alves, 1252, Vila Mariana, São Paulo, SP, Brasil

e-mail: delfava@biologico.sp.gov.br
} 


\section{Introduction}

Neospora caninum is a protozoan belonging to the phylum Apicomplexa, family Sarcocystidae, that mainly causes abortion in cattle, but its impact as causative agent of neurological syndromes has been poorly documented (DUBEY; SCHARES, 2006).

Infected calves may be born underweight, unable to rise and with no clinical signs of disease. Hind limbs, forelimbs or both may be flexed or hyper-extended. Neurologic examination may reveal ataxia, decreased patellar reflexes, and loss of conscious proprioception. Calves may show exophthalmia or asymmetric eyes. $N$. caninum occasionally may cause birth defects, including hydrocephalus and narrowing of the spinal cord (BARR et al., 1991, 1993; DUBEY et al., 1990,1998a; DUBEY; LAHUNTA, 1993; DE MEERSCHMAN et al., 2005).

There are few reports of the occurrence of the parasite in congenitally infected calves with neurological signs (DUBEY; SCHARES, 2006). Encephalomyelitis was the predominant lesion in live born calves but clinically affected or that developed clinical disease soon after birth and were necropsied by 2 weeks of age (PARISH et al., 1987; O'TOOLE; JEFFREY, 1987; DUBEY et al., 1989, 1992; BARR et al., 1991, 1994; MAGNINO et al., 1999; DE MEERSCHMAN et al., 2005).

In Brazil, cases of neurological syndrome associated with $N$. caninum in calves have been reported. Locatelli-Dittrich et al. (2003) isolated the protozoan in a 3-month-old Jersey calf in Paraná State, which presented with blindness. Santos et al. (2006), also in Paraná State, reported the occurrence of encephalitis in a 21 day-old Jersey calf infected with $N$. caninum.

The World Organization for Animal Health requires the diagnosis of causative agents of encephalitis for compliance with international sanitary standards for trade of animals and animal products (OIE, 2010). Many countries have implemented new diagnostic techniques and applied them in epidemiological studies in order to participate in the global marketplace and to guarantee food safety.

The Brazilian Ministry of Agriculture, Livestock, and Food Supply (MAPA) coordinates the National Program for Herbivore Rabies Control (PNCRH), and for encephalitis and encephalopathy epidemiological surveillance (BRASIL, 2009). In order to comply with the PNCRH, laboratories that perform rabies diagnoses are encouraged to conduct differential diagnosis of other etiological agents causing neurological syndromes when the CNS is negative for rabies virus. A preliminary study using PCR of neosporosis as a neurological syndrome in cattle in São Paulo State found $0.7 \%(1 / 131)$ of CNS specimens to be positive (DEL FAVA; PITUCO, 2010). Patrício (2008) assessed 253 brain specimens from 161 adult cattle and 92 calves with neurological signs from various regions of Paraná State, and detected 28 (11.07\%) positive specimens by PCR (primers $\mathrm{Np} 21$ and Np6) as follows: five 0-12 months old, six 12-24 months old, two 24-36 months old, and $15>36$ months old.

Immunohistochemistry (IHC) is highly specific when used to identify $N$. caninum in tissue sections (LINDSAY; DUBEY, 1989), but must be interpreted in conjunction with histological analysis, i.e., the presence of the parasite in tissue must be associated with inflammatory lesions and tissue necrosis (BARR et al., 1994; ANDERSON et al., 2000). To improve the sensitivity and specificity of $N$. caninum diagnosis, several PCR protocols have been developed focusing on the ITS 1 and Nc5 specific sequences to these protozoa, such as hemi-nested and nested-PCR (COLLANTES-FERNÁNDEZ et al., 2002; CABRAL et al., 2009).

The aim of this study was to examine the differential diagnosis for $N$. caninum in CNS of cattle with neurological syndrome that tested negative for rabies using hematoxylin-eosin (HE) staining of paraffin embedded tissue, immunohistochemistry (IHC), and nested-PCR using primers from the Nc5 region of the genomic DNA and ITS1 region of the ribosomal DNA.

\section{Material and Methods}

All procedures conformed to animal experimentation ethical principles adopted by the Brazilian College of Animal Experimentation (COBEA), and approved by the Animal Experimentation Ethics Committee of the Instituto Biológico (CETEA-IB no 092/09).

Three hundred and two specimens from bovid CNS sent from January 2007 to April 2010 to the Centro de Pesquisa e Desenvolvimento de Sanidade Animal do Instituto Biológico were initially examined for rabies by immunofluorescence (FAT) according to Dean et al. (1996) using anti-rabies conjugate labeled with fluorescein isothiocyanate $\left(\right.$ Sanof $\left.^{\circledast}\right)$. Specimens that were negative for rabies were examined for $N$. caninum infection by histological methods ( $\mathrm{HE}$ and IHC), and two protocols of nested-PCR.

Tissue specimens were fixed in $10 \%$ buffered formalin, embedded in paraffin, and $4-\mu \mathrm{m}$ sections were prepared and stained with $\mathrm{HE}$ for routine histological examination. A second set of sections were mounted on slides, along with controls, and processed for IHC according to Cabral et al. (2009) using avidinbiotin-complex peroxidase (Vector Elite ABC-peroxidase ${ }^{\circledast}$ ). As a positive control, goat fetal heart was taken from a pregnant goat that had been inoculated with the Illinois-NC strain of $N$. caninum. The IHC negative control was not exposed to the primary antibody. All slides were hydrated, and endogenous peroxidase was blocked by a combination of $10 \mathrm{~mL}$ of $30 \%$ hydrogen peroxide, $10 \mathrm{~mL}$ methanol, and $80 \mathrm{~mL}$ buffer. Slides were placed in a microwave oven at 800 watts for 10 minutes for antigen retrieval. Non-specific reactions were blocked with $10 \%$ milk powder dissolved in PBS.

The primary polyclonal antibody, anti- $N$. caninum rabbit hyperimmune serum, was diluted at 1:2000. The DAB chromogen (Data Sheet-Liquid DAB Substrate Pack, concentrated - VECTOR ${ }^{\oplus}$ ) was used for display and disclosure of the reaction. Sections were counterstained with Mayer's hematoxylin and examined microscopically.

Genomic DNA was extracted from fresh and frozen tissue using Wizard Genomic DNA Purification Kit - Promega ${ }^{\oplus}$, following the manufacturer's instructions. One hundred $\mu \mathrm{L}$ of DNA hydration solution was added to the pellet, which was then heated for 1 hour at $64{ }^{\circ} \mathrm{C}$. Specimens were stored at $-80{ }^{\circ} \mathrm{C}$ for nested-PCR. Two nested-PCR protocols were conducted using primers from the Nc5 region of the genomic DNA (genomic 
nested-PCR) and ITS1 region of the ribosomal DNA (ribosomal nested-PCR). For the genomic nested-PCR, pairs of NP21 and NP6 primers (5' GGGTGTGCGTCCAATCCTGTAAC $3^{\prime}$ - 5' CTCGCCAGTCAACCTACGTCTTCT 3') were used to amplify the $337 \mathrm{bp}$ DNA fragment and NP6-NP7 (5 'CAGTCAACCTACGTGTTAT 3'- 5' GGGTGAACCGAGGGAGTTG 3'), which amplified 227 bp of the Nc5 gene of $N$. caninum (HUGHES et al., 2006). Five $\mu \mathrm{L}$ of the DNA sample were added to the PCR mix making a final $20 \mu \mathrm{L}$ solution with commercial buffer from a Promega PCR Master $\mathrm{Mix}^{\mathrm{TM}}$ kit (M7502) and $0.2 \mu \mathrm{M}$ of each primer. The amplification was a modification of Hughes et al. (2006). The first amplification was 1 cycle of $95^{\circ} \mathrm{C}$ for 5 minutes, 40 cycles of $94^{\circ} \mathrm{C}$ for 1 minute, $60{ }^{\circ} \mathrm{C}$ for 1 minute, $72{ }^{\circ} \mathrm{C}$ for 1 minutes, 1 cycle of $72{ }^{\circ} \mathrm{C}$ for 10 minutes, and maintenance at $4{ }^{\circ} \mathrm{C}$. The second amplification was the same using $5 \mu \mathrm{L}$ of the first amplification product. For ribosomal nested-PCR, pairs of JB1 - JB2 primers (5'AGGAAGGAGAAGTCGTAACAAGG3 '- 5'GAGCCAAGACATCCATTGC3') were used to amplify the 500 bp DNA fragment and SF1 - SF2 (5 'CCTGTGAGTTGTATCGCCTTC3' 5 'TCTCTTCCCTCAAACGCTATCC3 ') to amplify 250 bp of the ITS1 region of ribosomal DNA from $N$. caninum (BARRATT et al., 2008). Five $\mu \mathrm{L}$ of the DNA sample were added to the PCR mix, and a final $20 \mu \mathrm{L}$ solution was made with buffer from the commercial kit Promega PCR Master Mix ${ }^{\mathrm{TM}}$ (M7502) and $0.5 \mu \mathrm{M}$ of each primer. The amplification was a modification of Barratt et al. (2008). The first amplification was: 1 cycle of $95^{\circ} \mathrm{C}$ for 5 minutes, 40 cycles of $94^{\circ} \mathrm{C}$ for 1 minute, $60^{\circ} \mathrm{C}$ for 1 minute, $72{ }^{\circ} \mathrm{C}$ for 1 minute, 1 cycle of $72^{\circ} \mathrm{C}$ for 5 minutes, and maintenance at $4^{\circ} \mathrm{C}$. The second amplification using $5 \mu \mathrm{L}$ of the first amplification product was: 1 cycle of $95^{\circ} \mathrm{C}$ for 5 minutes, 30 cycles of $94^{\circ} \mathrm{C}$ for $1 \mathrm{~min}, 60^{\circ} \mathrm{C}$ for 1 minute, $72{ }^{\circ} \mathrm{C}$ for 1 minute, 1 cycle of $72{ }^{\circ} \mathrm{C}$ for 5 minute, and maintenance at $4{ }^{\circ} \mathrm{C}$. The product of each amplification was applied to $2 \%$ agarose gel prepared in TAE $1 \mathrm{X}$ buffer (LGC ${ }^{\circ}$ ) and subjected to electrophoresis at a constant voltage of $100 \mathrm{~V}$ for 1 hour. The amplicons were visualized with ultraviolet light after ethidium bromide $\left(5 \mu \mathrm{g} \cdot \mathrm{mL}^{-1}\right)$ staining. The DNA fragment size was compared with a standard molecular weight (100 bp DNA ladder - FERMENTAS ${ }^{\oplus}$.

\section{Results, Discussion and Conclusions}

A total of 302 CNS specimens collected from cattle with neurological syndrome were analyzed. Convenience sampling was used, and diagnosis of encephalitis due to $N$. caninum was based on the presence of histological lesions, positive reaction with IHC, and two protocols of nested-PCR. According to Dubey et al. (1998b), tachyzoites or cysts of $N$. caninum are rarely sufficiently numerous to be found in all histological sections from an animal, requiring the use of specific and sensitive tests to detect the parasite. For this reason, histological findings should be interpreted as complementary to tests such as IHC and nested-PCR to identify the causative agent.

$N$. caninum causes multifocal necrosis in the CNS associated with mononuclear inflammatory infiltrate (PESCADOR et al.,
2007; CABRAL et al., 2009), and histological examination was used as a first screening method for lesions in the specimens. The most frequent histopathological changes found by HE were non-purulent meningoencephalitis in $24 \%$ (72) of the specimens studied, with none of them IHC-positive for $N$. caninum. The IHC protocol used negative control (positive block without primary antibody), and it did not show non-specific staining, while the positive control evidenced cysts with typical morphological structures intensely stained by DAB, confirming it as a very specific method, as reported by Cabral et al. (2009).

The genomic nested-PCR Nc5 revealed two positive cases $(0.66 \%)$ (Figure 1$)$, while the ribosomal nested-PCR ITS1 was negative. The sequence of primers from the NC5 region was not consistent with the genomes of Toxoplasma gondii, Sarcocystis capracanis, S. cruzi, S. miescheriana, S. moulei, S. tenella, or Hammondia hammondi (HUGHES et al., 2006), showing the specificity of the primers for Neospora.

The low frequency of CNS positive specimens for $N$. caninum found in this study agrees with that reported by Del Fava and Pituco (2011), who found $0.7 \%$ of neosporosis by PCR in CNS of 131 cattle with neurological syndrome that tested negative for rabies. In a similar study in the Paraná State, using a set of primers of the Nc5 region $(\mathrm{Np} 21 / \mathrm{Np} 6)$ and rabies negative bovine CNS specimens, Patrício (2008) found $11.07 \%$ positivity for N. caninum, though a histological evaluation to differentiate inflammatory lesions characteristic of $N$. caninum was not performed. It is thus not possible to determine if the positive nested-PCR represented disease (neurological syndrome) or latent infection.

In the present study, specimens came from 10 Brazilian states, of which 88\% (265) were from São Paulo, including the two animals testing positive with nested-PCR of the Nc5 region.

The most predominant breeds were zebu (Bos indicus, $42.0 \%$, $126)$ and cross-breeds $(28.0 \%, 86)$, followed by Bos taurus $(13.0 \%$, 38). In $17.0 \%$ (52) of the cases, the breed was unknown. The two animals $(0.66 \%)$ positive by genomic nested-PCR were cross-breeds. Most cattle were female $(69.0 \%, 208$ versus $27.0 \%$, 82 males); gender was unknown in $4.0 \%$ (12). The two positive animals were a male $(0.33 \%)$ and a female $(0.33 \%)$.

The animals were aged 0 to 18 years. Most were adults over two years old $(59.3 \%, 179)$, with $34.4 \%$ (104) younger than two years, and only $1.7 \%(5)$ were $<1$-month-old calves. Age was unknown for $6.3 \%$ (19). The low prevalence of disease in this study may be associated with the low number of animals at the age of risk, given that several authors report that calves with clinical neosporosis die within the first four weeks of life (DUBEY et al., 1992; BARR et al., 1993; DUBEY; LINDSAY, 1996).

The female testing positive by PCR, a 72 month-old crossbreed, did not exhibit pathological lesions in the CNS, and this may be considered a $N$. caninum latent infection. The positive PCR 20 month-old cross-breed male showed clinical signs of neurological syndrome such as sialorrhea, incoordination, recumbency and paddling, and opisthotonus, and died in four days. Histological examination of the CNS revealed severe multifocal necrosis in the neuropil (Figure 2), meningeal mononuclear infiltrate (Figure 3), and mononuclear perivascular cuffing (Figure 4). The clinical signs, histopathology, and PCR positivity implied that only the young male had encephalitis associated with $N$. caninum; therefore, the 


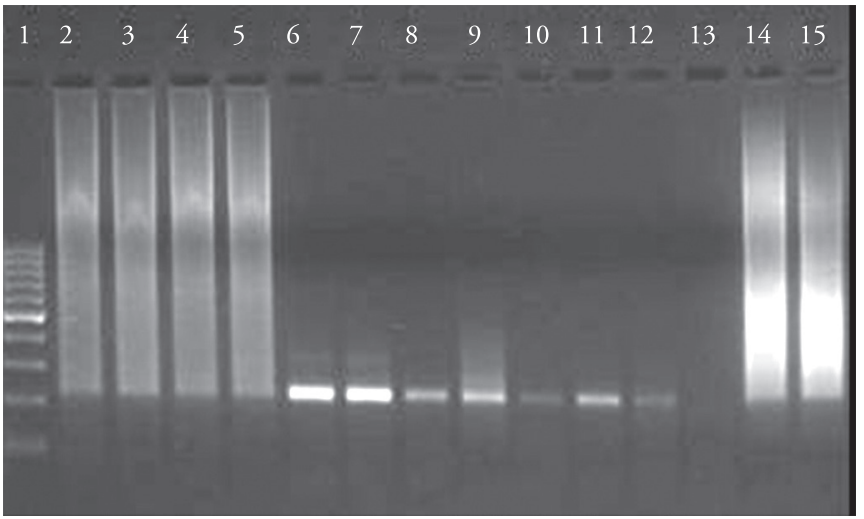

Figure 1. Genomic nested-PCR ( $\mathrm{Nc5}$ ) of $N$. caninum. Microwell 1) $100 \mathrm{bp}$ marker; Microwells 2-5) positive specimens (83 and 107 in duplicate). Microwell 6) N. caninum $\left(5.6 \times 10^{6}\right.$ tachyzoite $\left.\mathrm{mL}^{-1}\right)$. Microwells 7-12) N. caninum infectious doses $\left(10^{5}\right.$ to 1 tachyzoite $\left.\mathrm{mL}^{-1}\right)$. Microwell 13) negative control. Microwells 14 and 15) positive control.

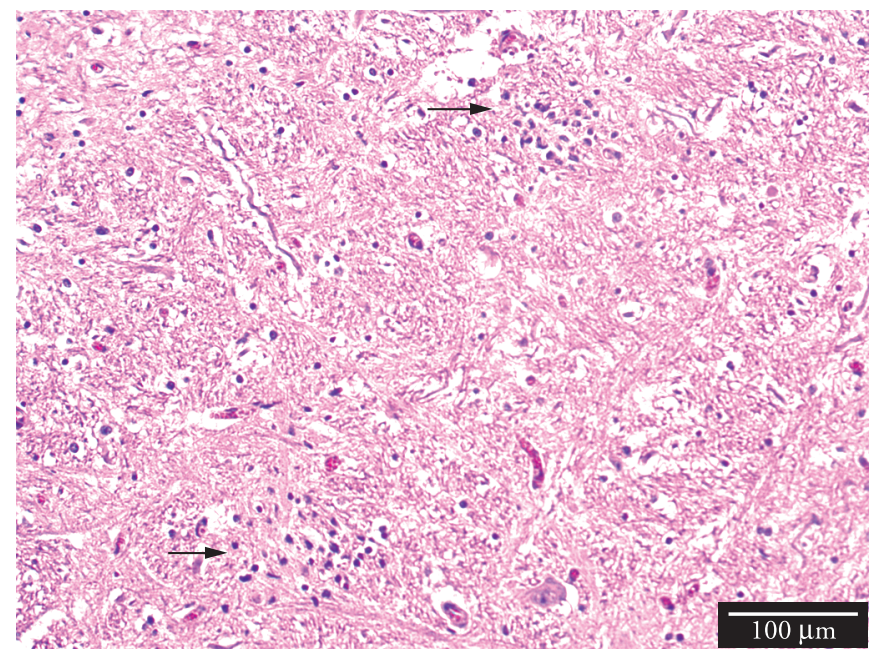

Figure 2. Multifocal necrosis associated to mononuclear inflammatory infiltrate. Bovine CNS positive with nested-PCR using primers from the $\mathrm{Nc} 5$ region of the $N$. caninum genomic DNA (HE staining).

proportion that best represents the positive cases of neurological syndrome caused by $N$. caninum in this study is $0.33 \%(1 / 302)$. This is the first report in Brazil of a bovine older than one year diagnosed with $N$. caninum-associated encephalitis.

Recent studies have associated inflammatory changes in the CNS identified by histology, positivity to molecular techniques and IHC to confirm active infection of $N$. caninum (OKEOMA et al., 2004; DUBEY; SCHARES, 2006; CABRAL et al., 2009).

When neosporosis is studied in mature animals, histopathologic findings should be combined with molecular analysis since the parasite may cause unrecognized chronic infection, or the animal may be an asymptomatic carrier, and no lesions are found because the animal is immunologically protected. The balance between the tachyzoite's ability to penetrate and multiply into host cells and the host's ability to inhibit parasite multiplication was discussed by Buxton et al. (2002) and Hemphill et al. (2006). The low prevalence of $N$. caninum in the CNS of young and

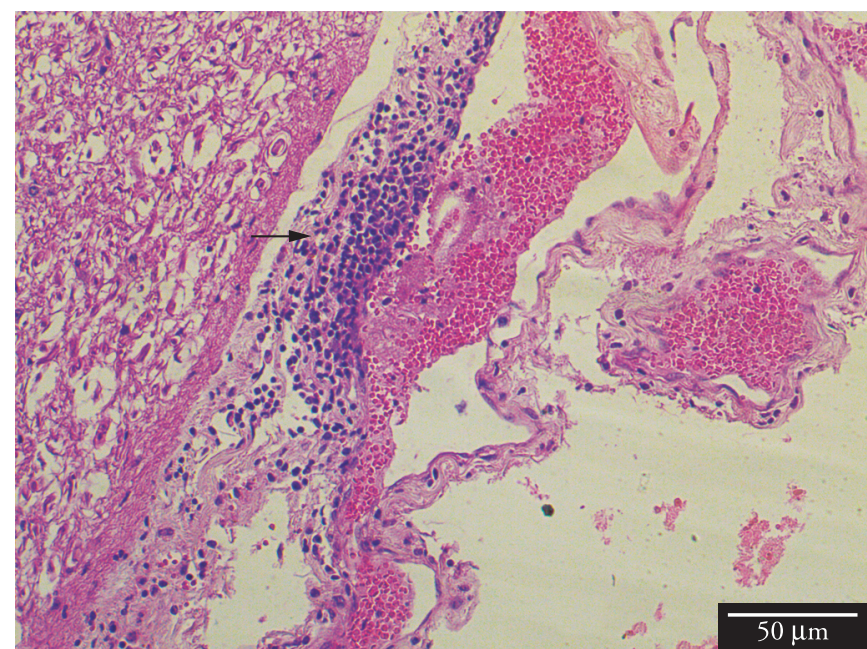

Figure 3. Congested meninges associated with severe and diffuse mononuclear inflammatory infiltration. Bovine CNS positive with nested-PCR using primers from the $\mathrm{Nc} 5$ region of the $N$. caninum genomic DNA (HE staining).

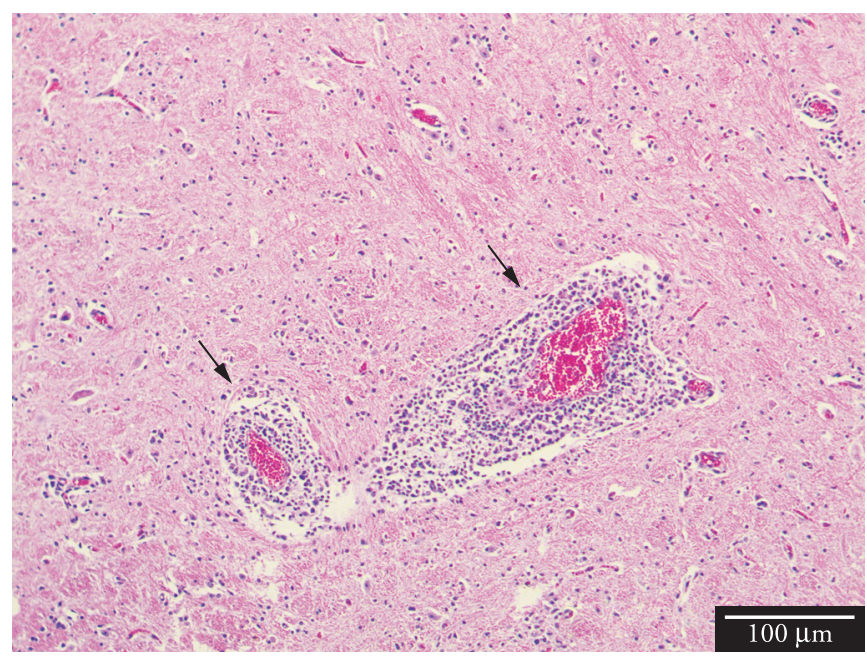

Figure 4. Congested blood vessels associated with severe mononuclear perivascular cuffing. Bovine CNS positive with nested-PCR using primers from the $\mathrm{Nc} 5$ region of the $N$. caninum genomic DNA (HE staining).

adult cattle suggests that the immune system responds efficiently to $N$. caninum through humoral immune response mediated by secreted antibodies, and by cellular immune response mediated by Th1 and Th2 (YAMANE et al., 2000; INNES et al., 2005; PINHEIRO et al., 2006; NISHI et al., 2009).

The present study applied a protocol suggested by Baszler et al. (1999) and Cabral et al. (2009) for routine diagnosis of N. caninum in aborted bovine fetuses using histopathology, PCR, and IHC. The majority of CNS specimens sent to the Instituto Biológico for histopathological examination of encephalitis were fixed in formalin, but some were chilled, or frozen, preventing histopathological and IHC diagnosis. Freezing and autolysis destroys the architecture of parasite cells, which can explain the non-visualization of parasitic cysts or tachyzoites by IHC, 
a technique that combines morphology and antigen binding antibodies marked with chromogen. Immunohistochemistry is a specific technique that has low sensitivity and can be effective when applied to intact tissues and those fixed in formalin (EPERON et al., 1999). Tissue fixation with formalin forms multiple connections with proteins (methylene bridges), which masks $N$. caninum epitopes, blocking the binding of antibodies to the antigen. Enzymatic or heat methods should be used for antigen retrieval to destroy methylene bridges and improve immunoreactivity (BOENISCH, 2005; KEY; BOENISCH, 2006; RAMOS-VARA et al., 2008). In the present study antigen retrieval from CNS-tissue containing paraffin blocks was improved by heating the slides in microwave oven, as described by Cabral et al. (2009).

Uggla et al. (1998) did not find either histopathological lesions or the parasite in brain specimens using IHC in inoculated calves; however, parasite DNA was detected, confirming that the test has greater sensitivity. An additional factor that may cause inconsistent detection rates of IHC and nested-PCR is the preservation of CNS specimens. Chilling, freezing and autolysis affect histological analysis (HE and IHC), and nested-PCR is a useful tool under these conditions. Because veterinarians use different methods for preservation of CNS specimens that are sent to laboratorial analysis, it is required for the detection of the parasite the association of techniques that are specific, such as IHC, or nested-PCR that are both specific and sensitive, preferably in conjunction with identification of histopathological lesions (SAGER et al., 2001). As autolysis is accelerated in the CNS, future studies should explore the association of IHC and nested-PCR with real-time PCR, a quantitative method (COLLANTES-FERNÁNDEZ et al., 2002) that could be standardized for improving the detection of $N$. caninum in CNS specimens of bovine with neurological syndrome. A manual for collecting, preserving and shipping CNS specimens for clinical encephalitis cases recommends that those from anatomic areas of CNS for microbiological and parasitological examination should be refrigerated, whereas those for histopathology examination must be fixed in $10 \%$ formalin, and only after that specimens should be sent for laboratory analysis (PITUCO et al., 2010).

The need for diagnosing causal agents of encephalitis is supported by the number of histopathological lesions that were found in CNS specimens undergoing routine analysis at the Instituto Biológico, i.e., 40\% (690) of cattle testing negative for rabies presented non-purulent meningoencephalitis (DEL FAVA et al., 2007). Histological, microbiological, and parasitological analyses are important for the differential diagnosis of etiologic agents of encephalitis, and veterinarians should be encouraged to increase the number of CNS specimens sent for screening.

With respect to $N$. caninum, based on the results of this study, sampling should include animals aged 0 to 2 years to provide new epidemiological data, support the encephalitis control program (BARROS; MARQUES, 2003; DEL FAVA et al., 2007; BRASIL, 2009), and determine the actual occurrence of $N$. caninum as a causal agent of encephalitis in Brazilian herds, contributing to the PNCRH surveillance.

\section{Acknowledgements}

We thank FAPESP for its financial support (grant 2009/11366-0), and TT-1 grant (process number 2010/05493-7 and 2010/06359-2); CNPq for a Master's grant (process number 135297/2009-5), and Prof. Dr. Milton McAllister for providing the positive control paraffin block, and primary polyclonal antibody against $N$. caninum for immunohistochemistry.

\section{References}

Anderson ML, Andrianarivo AG, Conrad PA. Neosporosis in cattle. Anim Reprod Sci 2000; 60-61(2): 417-431. http://dx.doi.org/10.1016/ S0378-4320(00)00117-2

Barr BC, Anderson ML, Dubey JP, Conrad PA. Neospora-like protozoal infections associated with bovine abortions. Vet Pathol 1991; 28(2): 110116. PMid:2063512. http://dx.doi.org/10.1177/030098589102800202

Barr BC, Conrad PA, Breitmeyer R, Sverlow K, Anderson ML, Reynolds $\mathrm{J}$, et al. Congenital Neospora infection in calves born from cows that had previously aborted Neospora-infected fetuses: four cases (1990-1992). J Am Vet Med Assoc 1993; 202(1): 113-117. PMid:8420896.

Barr BC, Rowe JD, Sverlow KW, Bondurant RH, Ardans AA, Oliver MN, et al. Experimental reproduction of bovine fetal Neospora infection and death with a bovine Neospora isolate. J Vet Diagn Invest 1994; 6(2): $207-$ 215. PMid:8068753. http://dx.doi.org/10.1177/104063879400600212

Barratt J, Qassab AS, Reichel PM, Ellis TJ. The development and evaluation of a nested PCR assay for detection of Neospora caninum and Hammondia heydorni in feral mouse tissues. Mol Cell Probes 2008; 22(4): 228-233. PMid:18420378. http://dx.doi.org/10.1016/j.mcp.2008.03.001

Barros CSL, Marques GHF. Procedimentos para o diagnóstico de doenças do sistema nervoso central de bovinos. Brasília: MAPA/SDA/DDA; 2003.

Baszler TV, Gay LJC, Long MT, Mathison BA. Detection by PCR of Neospora caninum in fetal tissues from spontaneous bovine abortions. J Clin Microbiol 1999; 37(12): 4059-4064. PMid:10565932. PMCid:85881.

Boenisch T. Effect of heat-induced antigen retrieval following inconsistent formalin fixation. Appl Immunohistochem Mol Morphol 2005; 13(3): 283286. http://dx.doi.org/10.1097/01.0000146524.74402.a4

Brasil. Ministério da Agricultura, Pecuária e Abastecimento.Programa Nacional de Controle da Raiva dos Herbivoros e outras Encefalopatias [online]. 2009. [cited 2011 Nov 30]. Available from: http://www. agricultura.gov.br/animal/sanidade-animal

Buxton D, Mcallister MM, Dubey JP. The comparative pathogenesis of neosporosis. Trends Parasitol 2002; 18(12):546-552. http://dx.doi. org/10.1016/S1471-4922(02)02414-5

Cabral AD, Camargo CN, Galleti NT, Okuda LH, Pituco EM, Del Fava C. Diagnosis of Neospora caninum in bovine fetuses by histology, immunohistochemistry, and nested-PCR. Braz J Vet Parasitol 2009; 18(4): 14-19.

Collantes-Fernández E, Zaballos A, Álvarez-García G, Ortega-Mora L. Quantitative detection of Neospora caninum in bovine aborted fetuses and experimentally infected mice by real-time PCR. J Clinical Microbiol 2002; 40(4): 1194-1198. PMid:11923330. PMCid:140374. http://dx.doi.org/10.1128/JCM.40.4.1194-1198.2002 
Dean DJ, Abelseth MK, Atanasiu P. Routine laboratory procedures: The fluorescent antibody test. In: Meslin FX, Kaplan MM, Koprowski H. Laboratory techniques in rabies. $4^{\text {nd }}$ ed. Genebra: World Health Organization; 1996. p. 88-95.

Del Fava C, Macruz R, Lara MCCSH, Cunha EMS, Villalobos EMC, Okuda LH, et al. Diagnóstico de encefalites e encefalopatias espongiformes transmissíveis em ruminantes no período de 2004 a 2007 no Estado de São Paulo, Brasil. [cited 2012 Jan 10] . Arch Vet Sci [online]. Avaiable from: http://ojs.c3sl.ufpr.br/ojs2/index.php/veterinary/article/ view/11153/7651.

Del Fava C, Pituco EM. Diagnóstico da Encefalopatia Espongiforme Bovina (Mal da Vaca Louca) [online]. 2011. [cited 2011 Jan 5]. Comunicados técnicos, n. 153. Avaiable from: http://www.biologico.sp.gov.br/ artigos_ok.php?id_artigo=153.

De Meerschman F, Focant C, Detry J, Rettigner C, Cassart D, Losson B. Clinical, pathological and diagnostic aspects of congenital neosporosis in a series of naturally infected calves. Vet Rec 2005; 157(4): 115-118. PMid:16040945.

Dubey JP, Leathers CW, Lindsay DS. Neospora caninum-like protozoon associated with fatal myelitis in newborn calves. J Parasitol 1989; 75(1): 146-148. PMid:2493086. http://dx.doi. org/10.2307/3282954

Dubey JP, Miller S, Lindsay DS, Topper MJ. Neospora caninum - associated myocarditis and encephalitis in an aborted calf. $J$ Vet Diagn Invest 1990; 2(1): 66-69. PMid:2090271. http://dx.doi. org/10.1177/104063879000200113

Dubey JP, Janovitz EB, Skowronek AJ. Clinical neosporosis in a 4-weekold Hereford calf. Vet Parasitol 1992; 43(1-2): 137-141. http://dx.doi. org/10.1016/0304-4017(92)90056-F

Dubey JP, De Lahunta A. Neosporosis associated congenital limb deformities in a calf. Appl Parasitol 1993; 34(4): 229-233. PMid:8298654.

Dubey JP, Lindsay DS. A review of Neospora caninum and neosporosis. Vet Parasitol 1996; 67(1-2):1-59. http://dx.doi.org/10.1016/S03044017(96)01035-7

Dubey JP, Abbitt B, Topper MJ, Edwards JF. Hydrocephalus associated with Neospora caninum-infection in an aborted bovine fetus. J Comp Pathol 1998a; 118(2): 169-173. http://dx.doi.org/10.1016/S00219975(98)80010-8

Dubey JP, Lindsay DS, Speer CA. Structures of Toxoplasma gondii tachyzoites, bradyzoites and sporozoites and biology and development of tissue cysts. Clin Microbiol Rev 1998b; 11(2): 267-299. PMid:9564564. PMCid:106833.

Dubey JP, Schares G. Diagnosis of bovine neosporosis. Vet Parasitol 2006; 140(1-2):1-34. PMid:16730126. http://dx.doi. org/10.1016/j.vetpar.2006.03.035

Eperon S, Brönnimann K, Hemphill A, Gottstein B. Susceptibility of B-cell deficient C57BL/6 (microMT) mice to Neospora caninum infection. Parasite Immunol 1999; 21(5):225-236. PMid:10320620. http://dx.doi.org/10.1046/j.1365-3024.1999.00223.x

Hemphill A, Vonlaufen N, Naguleswaran A. Cellular and immunological basis of the host-parasite relationship during infection with Neospora caninum. Parasitol 2006; 133(3): 261-278. PMid:16753081. http://dx.doi.org/10.1017/S0031182006000485

Hughes JM, Williams RH, Morley EK, Cook DAN, Terry RS, Murphy RG et al. The prevalence of Neospora caninum and co-infection with
Toxoplasma gondii by PCR analysis in naturally occurring mammal populations. Parasitol 2006; 132(1): 29-36.

Innes EA, Wright S, Bartley P, Maley S, Macaldowie C, Esteban-Redondo I, et al. The host-parasite relationship in bovine neosporosis. Vet Immunol Immunopathol 2005; 108(1-2):29-36. PMid:16098610. http://dx.doi. org/10.1016/j.vetimm.2005.07.004

Key M, Boenisch T. Antigen Retrievel. In: Key M. Immunohistochemical staining methods. $4^{\text {th }}$ ed. Carpinteria: Dako Corporation; 2006. p. 41-45.

Lindsay DS, Dubey JP. Immunohistochemical diagnosis of Neospora caninum in tissue sections. Am J Vet Res 1989; 50(11): 1981-1983.

Locatelli-Dittrich R, Richartz RRTB, Gasino-Joineau ME, Pinckney $\mathrm{RD}$, De Sousa RS, Leite LC et al. Isolation of Neospora caninum from a blind calf in Paraná, southern Brazil. Vet Rec 2003; 153(12): 366-367. PMid:14533770. http://dx.doi.org/10.1136/vr.153.12.366

Magnino S, Vigo PG, Fabbi M, Colombo M, Bandi C, Genchi C. Isolation of a bovine Neospora from a newborn calf in Italy. Vet Rec 1999; 144(16): 456.

Nishi SM, Viero, LM, Soares RM, Maiorka PC, Gennari, SM. Emprego da RT-PCR em tempo real para a quantificação da expressão de genes associados à resposta imune em bezerros bovinos experimentalmente infectados por Neospora caninum. BrazJ Vet Parasitol 2009; 18(S1): 8-14.

World Organization for Animal Health - OIE. Terrestrial Animal Health Code [online]. 2010. [cited $2010 \mathrm{Jul}$ 01]. Available form: http://www. oie.int/international-standard-setting/terrestrial-code/access-online/.

Okeoma CM, Williamson NB, Pomroy WE, Stowell KM, Gillespie LM. Isolation and molecular characterization of Neospora caninum in cattle. New Zeal Vet J 2004; 6(52): 364-370. PMid:15768137. http://dx.doi. org/10.1080/00480169.2004.36453

O’Toole D, Jeffrey M. Congenital sporozoan encephalomyelitis in a calf. Vet Rec 1987; 121(24): 563-566. PMid:3124328.

Parish SM, Maag-Miller L, Besser TE, Weidner JP, Mcelwain T, Knowles DP, et al. Myelitis associated with protozoal infection in newborn calves. J Am Vet Med Assoc 1987; 191(12): 1599-1600. PMid:3693018.

Patrício MAC. Investigação de neosporose em encéfalos de bovinos pela técnica de reação em cadeia da polimerase (PCR), com quadro de encefalopatia e diagnóstico negativo para Raiva, no Estado do Paraná, Brasil [Dissertação]. Curitiba: Universidade Federal do Paraná; 2008.

Pescador CA, Corbellini GL, Oliveira CE, Raymundo DL, Driemeier D. Histopathological and immunohistochemical aspects of Neospora caninum diagnosis in bovine aborted fetuses. Vet Parasitol 2007; 150 (1-2): 159-163. PMid:17904290. http://dx.doi.org/10.1016/j. vetpar.2007.08.028

Pinheiro AM, Costa SL, Freire SM, Meyer R, Almeida MAO, Tardy M, et al. Neospora caninum: infection induced IL-10 overexpression in rat astrocytes in vitro. Exp Parasitol 2006; 112(3): 193-197. PMid:16332369. http://dx.doi.org/10.1016/j.exppara.2005.10.008

Pituco EM, Del Fava C, Ribeiro, CP, Bersano, JG, Miyashiro, S. Sistema nervoso central (SNC). In: Centro Panamericano de Fiebre Aftosa - PANAFTOSA, Organização Pan-Americana da Saúde - OPAS, Organização Mundial da Saúde - OMS. Manual veterinário de colheita $e$ envio de amostras: manual técnico. Rio de Janeiro: PANAFTOSA/ OPAS/OMS; 2010. p. 128-137. Cooperação Técnica MAPA/OPASPANAFTOSA para o fortalecimento dos programas de saúde animal do Brasil. (Série de Manuais Técnicos, 13). 
Ramos-Vara JA, Kiupel M, Baszler T, Bliven L, Brodersen B, Chelack $\mathrm{B}$, et al. Suggested guidelines for immunohistochemical techniques in veterinary diagnostic laboratories. J Vet Diagn Invest 2008; 20(4): 393413. PMid:18599844. http://dx.doi.org/10.1177/104063870802000401

Sager H, Fischer I, Furrer K, Strasser M, Waldvogel A, Boerlin P, et al. A swiss case-control study to assess Neospora caninum associated bovine abortions by PCR, histopathology and serology. Vet Parasitol 2001; 102(1-2): 1-15. http://dx.doi.org/10.1016/S0304-4017(01)00524-6

Santos APME, Navarro IT, Vidotto O, Bracarense APFRL. Encefalomielite congênita em bezerro associada ao Neospora caninum no estado do Paraná, Brasil. Semina: Ci Agr 2006; 27(1): 111-114.
Uggla A, Stenlund S, Holmdahl OJ, Jakubek EB, Thebo P, Kindahl $\mathrm{H}$, et al. Oral Neospora caninum inoculation of neonatal calves. Int J Parasitol 1998; 28(9): 1467-1472. http://dx.doi.org/10.1016/S00207519(98)00110-6

Yamane I, Kitani H, Kokuho T, Shibahara T, Haritani M, Hamaoka T et al. The inhibitory effect of interferon gamma and tumor necrosis factor alpha on intracellular multiplication of Neospora caninum in primary bovine brain cells. J Vet Med Sci 2000; 62(3); 347-351. PMid:10770613. http:// dx.doi.org/10.1292/jvms.62.347 